'This article is (C) Emerald Group Publishing and permission has been granted for this version to appear here (please insert the web address here). Emerald does not grant permission for this article to be further copied/distributed or hosted elsewhere without the express permission from Emerald Group Publishing Limited.'

\title{
THREE SHADES OF EMBEDDEDNESS, STATE CAPITALISM AS THE INFORMAL ECONOMY, EMIC NOTIONS OF THE ANTI-MARKET, AND COUNTERFEIT GARMENTS IN THE MAURITIAN EXPORT PROCESSING ZONE
}

Patrick Neveling

\begin{abstract}
Purpose - This paper furthers the analysis of patterns regulating capitalist accumulation based on a historical anthropology of economic activities revolving around and within the Mauritian Export Processing Zone (EPZ).

Design/methodology/approach - This paper uses fieldwork in Mauritius to interrogate and critique two important concepts in contemporary social
\end{abstract}

Production, Consumption, Business and the Economy: Structural Ideals and Moral Realities Research in Economic Anthropology, Volume 34, 65-94

Copyright (C) 2014 by Emerald Group Publishing Limited

All rights of reproduction in any form reserved ISSN: 0190-1281/doi:10.1108/S0190-128120140000034002 
theory - "embeddedness" and "the informal economy." These are viewed in the wider frame of social anthropology's engagement with (neoliberal) capitalism.

Findings - A process-oriented revision of Polanyi's work on embeddedness and the "double movement" is proposed to help us situate EPZs within ongoing power struggles found throughout the history of capitalism. This helps us to challenge the notion of economic informality as supplied by Hart and others.

Social implications - Scholars and policymakers have tended to see economic informality as a force from below, able to disrupt the legalrational nature of capitalism as practiced from on high. Similarly, there is a view that a precapitalist embeddedness, a "human economy," has many good things to offer. However, this paper shows that the practices of the state and multinational capitalism, in EPZs and elsewhere, exactly match the practices that are envisioned as the cure to the pitfalls of capitalism.

Value of the paper - Setting aside the formal-informal distinction in favor of a process-oriented analysis of embeddedness allows us better to understand the shifting struggles among the state, capital, and labor.

Keywords: Capitalism; export processing zone; Polanyi; Mauritius

\section{INTRODUCTION}

Export processing zones (EPZs) have been central to the globalization that has happened in light-industrial manufacturing sectors such as textiles, garments, and light consumer electronics since the end of the Second World War. Accordingly, EPZs, and their most recent relabeling as Special Economic Zones (SEZs), have for long been an important concern for economic anthropologists (e.g. Nash \& Fernández-Kelly, 1983; Ong, 1987). Recently anthropologists have developed a renewed interest, identifying the zones either as harbingers of neoliberalism in Southeast Asian economies (Ong, 2006) or in explicit opposition to this, as mere extensions of informal employment regimes that Indians have witnessed since the colonial era (Cross, 2010). Elsewhere I have argued that anthropology's analysis is best advanced if we consider neoliberalism as one of several possible manifestations of "capitalist accumulation and their regulation by nation-states and 
international organisations" (Neveling, 2014, p. 19). This shifts our understanding from neoliberalism as an all-encompassing historical phenomenon to the analysis of capitalism and its untimely coincidences and "structured contingencies" (cf. Kalb, 2012) in patterns of regulating exploitation.

This paper takes that concern further, based on the example of the Mauritius Export Processing Zone (MEPZ). The MEPZ was established by the Mauritian state in 1970, only two years after independence, with the aim of boosting economic development by attracting foreign investors. As with all EPZs established since 1947, incentives were the paramount means to attract foreign investors and included waivers of tax and customs payments for a given number of years, low-cost rental or lease of state-built industrial infrastructure, and the promise of a cheap workforce without the right of unionization (Neveling, 2015a). Reference to the "nimble fingers" of Mauritian women should further arouse investors' imaginations of highly productive young Third-World women workers. This is a common trope in EPZs across the globe, and anthropologists have long pointed to the "orientalist" view that investors have of women EPZ workers (e.g., FernándezKelly, 1983, p. 42).

In Mauritius, as in many other nations, promoting the EPZ was a matter near to the bureaucracy's heart. The Development Bank of Mauritius (DBM), which ran the EPZ, and the overseeing Ministry of Commerce and Industry printed glossy brochures with rich illustrations and bullet-point listings of all these incentives - including the nimble fingers, the high standard of modern Mauritian industrial buildings, and the pleasures of island life - to be handed out to investors in the thousands (e.g., Ministry of Commerce \& Industry, 1973). The fact that the political and legal system in Mauritius was stable and investor friendly and that the state put lots of money into economic development was publicized globally, with large advertisements in international newspapers drawing attention to each amendment of the Mauritian EPZ Act and to each new fiscal measure that put more money into the MEPZ (e.g., Ministry of Commerce \& Industry (Mauritius), 1973, 1976). In other words, the MEPZ was very much a state affair. Supported by advisors from international creditors and donors such as the World Bank and the United Nations Industrial Development Organization, national bureaucracies took control of economic development and in many ways circumscribed the position of the national workforce.

The early years of MEPZ operations offer important insights into how nation-states and international organizations regulated capitalist accumulation in EPZs during the 1970s, when hundreds of today's more than 3,000 
zones became operational. Such insights are needed, because the abovementioned juxtaposition of the zones as emblems of neoliberalism, either of the exceptional or the unexceptional kind, offers nothing much but an impasse. The problem with anthropology's analysis of neoliberalism lies with its timing, with the notion that it is a watershed in human history coming as radical rupture (for these arguments see Baca, 2005, 2010; Neveling, 2006, forthcoming). What is brought forward in the critique of "neoliberalism as exception" (Ong, 2006) is that in regard to EPZs it "ignores how these spaces are structurally embedded in the wider economy" (Cross, 2010, pp. 369-70). The clash of arguments that might be intended here is one that resembles other debates in anthropology, where one scholar prefers a "worm's eye view" (Cross, 2010, p. 358), to the extent that enquiry starts with the workers digging the foundations of an EPZ, whereas another scholar has an eye on global conjunctures and sees EPZs as emblems of the "very strategy of graduated sovereignty that embeds society in global production and financial markets" (Ong, 2006, p. 92). Both paradigms are important for an anthropology interested in the patterns regulating capitalist accumulation. But neither offers insights into how regulation of such a particular arena of capitalist accumulation emerges, how it is perceived by the actors involved, and what anthropology should make of this in analytical terms so that findings exceed both the native's point of view and the metadescriptive level. New analytical insights may instead result from critical engagement with long-held categories in economic anthropology. The notion of embeddedness, for example, is important to both Ong and Cross, but employed to very different ends. Similarly, a critical evaluation of "informality" in EPZs is what Cross puts forward to counter Ong. Again, however, the scale of the analysis is problematic, because Ong is speaking about a global condition, whereas Cross refers to the particularities of the Indian setting.

This paper departs from the view of neoliberalism as structured contingency and untimely coincidence to develop alternative understandings of what formal and informal economic activities are and what embeddedness is. Based on a historical anthropology of the early years of MEPZ operations, "Section One" shows that state regulation of capitalist exploitation in EPZs amounts to the creation of informal economic activities in the eyes of all actors involved (workers, politicians, capitalists, ordinary citizens). Because this is so, I propose a revision of anthropology's long-held understanding of the "informal economy" as the antithesis of "state capitalism" (Hart, 2005, p. 6), which I base on Fernand Braudel's classification of capitalism as an "anti-market." This anti-market is one of "three discrete, 
contemporaneous spheres of activity, ranging from self-provisionings of everyday life, to the fulfillment of needs in markets, to capitalism, the locus of monopolists and political predators interested in eliminating competition in economic transactions" (Blim, 2000, p. 27). In other words, state-actors and capitalists striving for sustainable accumulation are dependent on the inequality that comes with the anti-market and offers protection from actors playing by different rules.

I propose that we define the term embedded as having everyone play by the same rules. This requires an anti-market that is regulated nationally and internationally by laws, policed internally and externally accordingly, with limitations to the right of entry and codes of conduct that are widely accepted. This is an important amendment of anthropology's common notion of the workings of markets, which too often builds on the premise of a historical shift from regulated markets to self-regulated markets. Such a notion of radical rupture is particularly prominent in works that see the most recent era as one of "neoliberalism" (see above). But it stems in many ways from a distinction proposed by Polanyi between a "human economy" that is "embedded and enmeshed in institutions, economic and noneconomic" (Polanyi, 1957, p. 250) and a "market economy," where a selfregulating mechanism determines the production and distribution of goods that are exchanged in price-fixing markets (Polanyi, 1977, p. 102, my translation). Because such a self-regulating market takes a predominant stage in the organization of human life, the economy is said to be disembedded from other institutions of human life: the pre-self-regulated-market organizational principle is deemed "social"; the later principle is deemed "economic."

Other authors have suggested that even in a longer historical view, Polanyi was on the wrong track. Many features of self-regulating markets can be found much earlier than the mid-19th century, while features of regulated markets that Polanyi claims have vanished can actually be found in the present (Braudel, 1992, pp. 225-229). This is why it is misleading to call "one form of exchange economic and another social" (Braudel, 1992, p. 227). Economic sociologists and some social anthropologists nowadays propose that we speak of all economies as embedded (Barber, 1995; Rottenburg, Kalthoff, \& Wagener, 2000).

"Section Two" applies this understanding with Polanyi's second important dictum in mind, which says that a "double movement" results from the self-regulating market's disembedding effect. Those who suffer turn to the state for protection. Should they achieve significant institutional change, "embedded liberalism" may emerge. Again, empirical accuracy is an issue here, as Polanyi reserved the term double movement for estranged 
workers. But in the 20th century it was often capitalists who pressured the state to protect their interests. What Polanyi saw as an end of history, embedded liberalism, turns out to be an oscillating power struggle between labor and capital (Blyth, 2003, pp. 3-4). To capture the dynamics of the anti-market, "Section Two" goes beyond the winners and losers (capital versus labor) perspective as it considers how changes in patterns of regulating accumulation lead to clashes among capitalists. The case I present was hotly debated in Mauritius during my field research in 2003 and 2004. It had to do with conflicting anti-market regulations on national and international scales and emerged from the large-scale production and sale of counterfeit Ralph Lauren garments.

In the concluding section, I analyze these clashes and their resolution as moves from embeddedness, to disembeddedness, to reembeddedness. This way, attention to double movements and embeddedness allows for middlerange analyses that capture how patterns of regulation change over shorter time spans. The section also shows what is gained if we use the differentiation of formal and informal economic activities as a metadescriptive terminology that captures emic/actors' notions of one and the same economic activity within a given state-capitalist setting. This feeds back usefully into our process-oriented understanding of embeddedness as an analytical tool for capturing divergences and realignments of patterns regulating capitalism in the global system.

\section{SECTION ONE: THE MAURITIAN EXPORT PROCESSING ZONE AS INFORMAL STATE CAPITALISM}

One ambition of this paper is to take the analysis of patterns regulating capitalist accumulation further. For this it is instructive to enquire what the development of the MEPZ can tell us about anthropology's long-held concerns with the informal economy and with the embeddedness of market and society. The following addresses that issue and introduces the concept of a statist informal economy.

Keith Hart coined the term informal economy and established this as an "antithesis" to "state capitalism." The latter emerged in the mid-19th century as "an attempt to manage money and markets through national bureaucracy" (Hart, 2005, p. 6). Although the term state capitalism appeared later in Hart's work, the above juxtaposition was implicit in his 
groundbreaking 1973 article, which demonstrated that development economics' focus on employment in state-registered and regulated activities failed to account for the many activities by which the urban poor get by in the Ghanaian capital of Accra. There, the economic activities of peddlers, hawkers, petty criminals, and so forth had a much lesser "degree of rationalisation of work," and hence, such activities awarded less predictable income than stable state-registered employment (Hart, 1973, p. 68). ${ }^{1}$

Based on what has been said above about its establishment and international promotion, the MEPZ should make for an excellent example of Hart's "state capitalism." A law was passed in parliament to establish the EPZ; the DBM and the Ministry of Commerce and Industry ran the zone and were responsible for advertising it internationally. In the 1970s, the MEPZ was a state-driven economic initiative with a high degree of rationalization. Everything points to the MEPZ being a prototypical formal economic activity. If we take a closer look at the establishment and early operations of the MEPZ and its impact on everyday life on the island, a very different picture emerges, however. The following breaks this down for the metacategories capital, state, and labor and shows how informality emerges from the native's point of view rather than as an analytical category, which can be used to maintain or counter notions of radical rupture, such as neoliberalism.

\section{The MEPZ as Informal Through the Eyes of the State}

In 1961 Seewoosagur Ramgoolam, leader of the Mauritian Labour Party, went to London to negotiate independence for the British colony. Future prospects for the small island in the western Indian Ocean were anything but good. Economists and sociologists ranked Mauritius as a perfect case study for the (neo-)Malthusian trap: sugar cane was the country's only export commodity, since the end of the Second World War the population had grown rapidly, unemployment was high and rising, and the creation of new jobs seemed utopian (see Greenaway \& Milner, 1991, p. 326; Neveling, 2012, p. 261). The Colonial Office in London considered violent tensions between the different groups inhabiting the island to be a very likely scenario. This was because descendants of French colonizers, African slaves, and indentured laborers, mainly of Indian origin, were said to have different economic interests and positions (Colonial Office, 1959). 
The initial response from the colonial administration was to appoint two survey missions, one headed by a famous sociologist, Richard M. Titmuss, and one headed by a famous economist, James E. Meade, to suggest ways out of the crisis. The Titmuss mission designed a social security net for Mauritius, and the Meade mission proposed ways to diversify the economy from its heavy reliance on sugar, mainly by advising strong (colonial) state support for so-called pioneer industries that would produce commodities which Mauritius otherwise had to purchase on the world market and pay for in scarce foreign exchange. The success of these efforts by the late British colonial state was limited, however. Finding a way to achieve substantial economic development remained paramount after independence in 1968. Survey missions were sent out to evaluate development policies in Hong Kong, Ireland, Puerto Rico, Singapore, and Taiwan and returned with recommendations to set up an EPZ (Neveling, 2012, pp. 273-82).

Given that for the mid-2000s the International Labor Organization and the World Bank are counting around 3,500 EPZs and SEZs, it is nowadays rather common for nation-states to offer substantial incentives to investors, such as the tax and customs waivers I have mentioned above (cf. Boyenge, 2007). But in the late 1960s this was uncharted territory for most postcolonial nations. Therefore, even in a country as desperate as Mauritius, parliamentary readings of the EPZ Act during the legislature of 1970 were rather heated. Disputes cut across party lines as much as across the ethnic and religious groups that many anthropologists hold to be the fundamental patterns of sociability among Mauritians (e.g., Eriksen, 1998).

Opponents claimed the EPZ would cause a breakdown of moral order and attract few investors (Debates of the Legislative Assembly, 1970, pp. 1244-1256). Supporters saw immediate economic prosperity on the horizon and argued that the EPZ would make Mauritius known worldwide, attracting not only investors but also tourists (Debates of the Legislative Assembly, 1970, pp. 939-945). This was a strong argument, as by the late 1960 s, attracting tourism was another important development strategy for Mauritius (for an outline of the historical development of tourism in Mauritius, see Schnepel \& Schnepel, 2008, pp. 6-11). The strongest argument in favor of an EPZ was, however, that there already existed an EPZ-like factory in Mauritius. As early as 1965 the owner of Micro Jewels, a factory processing parts for Swiss watches, had obtained tax and customs exemptions by private lobbying in London, supported by Meade, who had led the economic survey mission to Mauritius in 1960 (personal conversation August 20, 2003; see also Burn, 1996). 
State capitalism in colonial times knew many such backchannels. Places like 1960s Mauritius were an ideal breeding ground for informal networks through which powerful players in business, the colonial state, education, and religious congregations secured or improved their positions. ${ }^{2}$ A club called Stella Clavisque ("the star and the key"), referring to Mauritius' strategic importance in the Indian Ocean before the opening of the Suez Canal, was of particular relevance to Mauritian early postcolonial history (cf. Neveling, 2015b), and so was the Rotary Club Port Louis, founded in 1964, with the owner of Micro Jewels serving as second president. Other members included the former director of the DBM and the later Minister of Commerce and Industry of 1970, who during the above-mentioned readings of the EPZ bill would present Micro Jewels as a shining example for the benefits of an EPZ (cf. Debates of Legislative Assembly, 1970, pp. 1181, 1256).

This surely helped to pass the EPZ Act. Besides considerable differences, there had also been common ground among members of parliament. One common theme was that the rights held by workers in other sectors would not attract foreign investors. Redundancy payments were quickly dismissed. Concern over a minimum wage and unionization was brushed aside with reference to the survey missions, which had underlined that EPZ factories would mainly hire women (Neveling, 2012, p. 277). Mauritius in this regard was similar to Caribbean countries where a "myth of the male breadwinner" (Safa, 1995) meant that women's labor was devalued by multinational corporations investing in EPZs as much as by local patriarchal structures (for details on gender and the MEPZ see Neveling, 2006, 2015b).

The fact that Mauritian MPs wittingly introduced what they considered to be informal economic practices is further evidenced in earlier parliamentary debates that considered whether tax and customs rebates for pioneering industries should be upheld by the postcolonial state. Even for these import-substituting industries, there was suspicion that such waivers came close to smuggling, as the following excerpt shows:

Mr. Ramallah: Government was very well advised to give such a rebate to the garment factories and today we are producing very fine garments, specially shirts. Ten years ago, people sneered at it when we said that we should manufacture garments, specially shirts (...) today our garments are fetching a good market abroad. I know a few friends who took with them some shirt from Mauritius, which they bought for Rs. 8 at a sale and sold these shirts in India at Rs. 35.

Mr. A. R. Mohamed: And they were not confiscated by the customs? (This remark causes general laughter). (Debates of the Legislative Assembly, 1968, p. 2983) 


\section{Preliminary Conclusions on Informal State Capitalism and Market Regulation}

In 1971 the government presented a 10-year development plan and promised the creation of 130,000 jobs within 10 years under the slogan "Discipline, travail et participation" (L'Express, 1971). Although 10 years later there were only about 20,000 jobs in EPZ factories, this was quite an accomplishment. The British colonial administration had struggled to create some 8,000 jobs in the highly subsidized pioneer industries of the 1960s, when the situation in Mauritius and in the global system was comparatively calm. The 1970s instead started off with the Mauritian government declaring a state of emergency in 1971 that would last for five years, with a global crisis in 1973, a national general strike in 1975, and another global crisis and national general strike in 1979.

Still, investors kept coming. Although the 1980s started off with a World Bank Structural Adjustment Programme and a landslide victory of the socialist party, EPZ investment reached unseen peaks. This was not because a self-regulated, neoliberal market had finally come about, but because state diplomacy secured preferential export quota for sugar to the European Economic Community under the Yaoundé Agreement and succeeding Lomé Agreements. Sugar prices rose during the world food crisis of 1973, and local capitalists put these revenues into the EPZ, where their capital was safe from nationalization and investment was tax free (Neveling, 2012, pp. 326-31). Another important regulation on the global scale played into Mauritian cards as well. The Multi-Fiber Arrangement of 1974 set quota limits for imports to Europe and North America from socalled Newly Industrializing Countries. In the early 1980s, Sri Lanka, Hong Kong, and Singapore reached their quota ceilings. As investors discovered the untapped Mauritian quota, a rush started, and official figures claimed full employment for 1990, while economists spoke of an "economic miracle" (cf. Aladin, 1993).

The story presented so far was prototypical for Third-World countries. Even though many zones were failures, EPZs became an ever more obvious step to successfully achieve economic diversification throughout the 1970s and 1980s. Most EPZ projects were built on expectations of export earnings, mass employment in industry, technology transfer, backward linkages with local businesses, and other important factors that would increase what was called "the formal sector" (cf. Neveling, forthcoming). But if we take a closer look at how Mauritian politicians perceived the EPZ, the story gets a twist. The praise for taking shirts to India and selling them there during a 
private journey and the laughter that followed during the bill readings of 1968 indicate that MPs imagined the EPZ as an informal economic practice.

In many ways, the findings from Mauritius echo observations for Latin American countries "where the state has consistently adopted antilabor and deregulatory policies and the [...] distinction between formal and informal sectors becomes blurred" (Portes \& Benton, 1984, p. 605). In Mauritius, blurring that distinction stood at the cradle of the EPZ. It is therefore worthwhile to broaden the picture and to question whether the factories that set up shop in MEPZ qualify as actors in a "formal economy" - and whether the EPZ regime qualifies as a globally salient phenomenon of state capitalism. The following shows that the viewpoints of capital and labor on the MEPZ were quite similar to those of politicians.

\section{The MEPZ as Informal in the Eyes of Labor}

Factory workers in Plaine Lauzun and Coromandel, the first state-run industrial estates, came from the poor areas that surround the capital, Port Louis, and the larger cities to the south. These had emerged from an earlier modernization project. In 1960, the colonial state had rehoused tens of thousands of poor Mauritians, whose dwellings had been destroyed by two cyclones. Ten years later, government land purchases for the construction of industrial estates were planned with the explicit aim to target the inhabitants of these cités (Development Bank of Mauritius/Gustave Rey, undated, around 1971). As more and more cité-dwellers took employment in EPZ factories, the settlements became known as cités ouvrières, "workers' housing estates."

These new workers soon renamed the "zone franche" into "zone souffrance," and for good reason. By shifting from the French phrase for "free zone" to "zone of suffering," workers referred to the fact that the state law denied them basic rights, such as unionization and minimum wages, which existed for workers in the sugar sector and for government employees. Relations on the shop floor were anything but dignified. Stories about degrading recruitment policies of the 1970s are abundant in Mauritius until today. If younger job seekers could not produce birth certificates or other proof of identity, managers conducted what they called "tit-tests," claiming this was the only way to verify whether the applicant was above the minimum working age of 14. Once workers were employed in an EPZ factory, sexual harassment continued, and there were numerous wildcat strikes because of physical violence by supervisors (Neveling, 2006). 
The perception of the EPZ by Mauritian workers mirrors observations from Latin America, namely that "[f]rom the perspective of people living on subsistence production or working in the informal sector it is rather the official and formal economy of large organizations and government bureaucracies which is a "shadow economy" (Evers, 1987, p. 364, my translation). In other words, the same stratum of poor urban dwellers that Hart encountered in Accra, and whose economic activities led him to juxtapose the terms informal economy and state capitalism, serves to illustrate the opposite, that state capitalism may well be perceived as the informal economy in Mauritius.

Recently, anthropologists have suggested highlighting continuities with informal economic relations of earlier days to fully capture working conditions in EPZs (Cross, 2010). The Mauritian example rather serves to highlight discontinuities. Workers in long-established economic sectors, such as technicians in the sugar mills or dock workers, had won the right to unionization and strike action in the late 1930s and early 1940s (Neveling, 2012, pp. 211-232). Employment relations in the very same sectors may have been different for day laborers and seasonal workers. But this had had to do with a lack of regulation from the colonial state and amendments that had been made in the 1960s. In the MEPZ instead, it was state regulation that encouraged and actually initiated new informal economic relations that in many ways reversed the achievements of labor during colonial times. Spirit possession that led to production stops in EPZ factories were one way such concerns were voiced; wildcat strikes were another; whereas complaints to the ministries had no resonance with a state that was quick to deploy riot police to beat up pickets (Neveling, 2015b).

These are vivid illustrations of the way the Mauritian state secured the operations of the EPZ anti-market. Labor was supposed to be cheap and docile from the viewpoint of investors, and anything else was unacceptable. In many ways, then, the "native's point of view" of politicians and workers on the Mauritian EPZ, if not taken "as an end in itself" (Carrier, 2012, p. 121) but as a means to produce further-reaching theoretical insights, confronts the anthropologist's point of view (i.e., that of Cross and Hart). Looking at the perceptions of capitalists operating in the MEPZ can further substantiate this assertion.

\section{The MEPZ as Informal in the Eyes of Capital}

A 1983 report by a leading analyst of the island's oldest bank, the Mauritius Commercial Bank, complained about "unverifiable" EPZ 
companies "rip[ping] off" the state as they used semi-legal employment to evade the few taxes payable (Forget, 1983, pp. 7-8). Other natives of the global capitalist system, foreign investors, instead wondered why longpracticed and elaborate management strategies used in industrially advanced countries could not increase Mauritian worker productivity. A garment manufacturer who came to the island in 1971 only got operations running at a profit, his daughter claimed (speaking to me in 2004), after German managers had been replaced with a retired British colonial army officer who introduced "childish incentives" for good performances, such as gifts of plastic bowls and other cheap household utensils. Other company managers I spoke to remembered how in the 1970s and 1980s many foreign investors felt cheated by local Mauritian banks. Their suspicion was that the Mauritius Commercial Bank, for example, was used by local businessmen to monitor which foreign-owned companies could reap the highest profits. If such a company had been identified, it would be drained of credit in those months when orders from Western markets came in and raw materials had to be bought. Once the end of the global garment market's low season had come and the company had been fully drained, it would be placed in receivership and auctioned off to one of the bank manager's many cousins. The harshest and most entertaining such story told of an Englishman who lost all his investment due to this modern form of privateering, something that left him so annoyed that he crashed his car into a pylon close to the airport and walked the last kilometer - just to leave nothing of value behind.

Economic anthropologists often identify those activities as informal, which are either ignored by or hidden from the state (cf. Cross, 2010; Hart, 1973). In Mauritius, however, the state consciously set up the EPZ with features that anthropologists take to be informal. This is even more striking because the EPZ was meant to become the backbone of national economic progress. As EPZ operations developed and became more refined, all actors involved realized that this was an arena of insecure and highly dubious economic transactions. Such state-sponsored transactions then indicate that anthropology's view of state capitalism is problematic and leads to misunderstandings, because capitalism is presented as a rationalized system of the Weberian type. As the above discussion has shown, capitalism is better understood as an anti-market that is actively upheld by the state.

I have now shown that the distinction of formal versus informal is best used to capture the emic perspective of actors involved in establishing a new pattern regulating capitalist exploitation, such as the MEPZ. For an analysis of such patterns, the formal-informal dichotomy is less useful. 
Therefore, I turn to another crucial aspect of anthropology's understanding of capitalism, Polanyi's distinction of "embedded" economies and "disembedded" economies. The following will show that once we trade Polanyi's evolutionist approach for a process-oriented understanding of embedding, disembedding, and reembedding the anti-market within a given economic arena, we can use this as a middle-range analysis of the contests between capitalist actors and/or institutions over defining the rules for transactions. These three shades of embeddedness then help to capture how highly regulated state-capitalist ventures such as the MEPZ produce a variety of double movements, because the outcomes of such ventures are "partially intended and partially unintended" (Rottenburg et al., 2000, p. 24).

\section{SECTION TWO: RALPH LAUREN - MAURITIAN STYLE; AND THE THREE SHADES OF EMBEDDEDNESS IN GLOBAL CAPITALISM}

Mauritius is rather an upmarket holiday destination, partly because the national tourism promotion agency has successfully created an image of Mauritius as somewhat equivalent with Tahiti, the Seychelles, or the Maldives. Hotel complexes ranging in ratings from three to five stars take up most of the good spots along the island's shore (cf. Schnepel, 2009). Similar to the EPZ, the percentage of local ownership is high in the hotel industry. This is facilitated by the fact that land ownership in the sugar industry was mainly local. Chains such as the Constance Hotels and Resorts Group and EPZ factories such as Ferney Spinning Mills still bear the names of sugar estates and are owned by consortia that emerged during the 1870s, 1930s, and 1970s, which were periods of centralization in the sugar sectors. ${ }^{3}$ Five-star hotels attract the full range of late modern capitalism's celebrities: the "A-class," such as David Beckham or Madonna, and the "C-class," such as the odd TV-show contest winner whose claim to fame has been prolonged by informal engagement with one or several "Aclass" members. The bulk of arrivals, however, are German, French, English, and Dutch tourists of middle-class income, mindset, and tastes, who find accommodation in the less fancy resorts and hotels. ${ }^{4}$

Such tourists may be attracted by images of white beaches, snorkeling the coral reefs, palm trees, and exotic food. But the local tourism industry eagerly adds culture to the tourist experience, for example by providing 
evening dance shows by the beach or in hotel restaurants that introduce tourists to the Mauritian Séga music (Schnepel \& Schnepel, 2009). While Séga is portrayed as a domain of the descendants of African slaves brought to the island to work in the French and early British period, encounters with descendants of other immigrant groups such as the Chinese coolies and merchants, the Gujarati traders, or the Indian indentured laborers, are offered as excursions visiting local markets and the small Chinatown in the capital. More intimate encounters include coming to the household of a local tour guide as the final stage of day trips to see "the real life" of Mauritians. The island's changing incorporation into the global capitalist system and the labor regimes that came along with this are displayed as lightly consumable versions and focus largely on events prior to independence. A museum on the history of the sugar industry, for example, is housed in a former sugar mill owned by one of the largest Mauritian consortia and called "L'aventure du Sucre." In sum, Mauritius is displayed as a tropical paradise that is exceptional in that many different ethnic groups live side-by-side in peace. Never accounted for are the persistence of grave inequalities, the general strikes and the rise of a socialist movement in the 1970s, or the World Bank and International Monetary Fund policies that ended this rise in the early 1980 s.

Coming to this setting with connections to be made and the small research budget of a Ph.D. student for preliminary research in 2003 was a challenge. Although I arrived in July, in the Mauritian winter when temperatures are in the lower 20s of the Celsius scale and tourist arrivals are few, it was difficult to find affordable accommodation not mainly catering for locals entertaining extramarital relations for a night or for foreign petty traders looking for a dodgy deal. After some days of searching, I settled for spending the first two weeks in a family-run hotel in a small village right on the road connecting the southern region with the capital, Port Louis. There, in Tamarin, Mauritius' "traditional" economic activities still had a strong presence. Sugar cane fields dominated the slopes rising to one of the island's plateaus to the east. Close to the beach looking westward to Tamarin Bay, there was a small cold store where fishermen kept their catch until the local cooperative's truck came for collection. At first sight, the only peculiarity was the island's largest desalination plant, located not far from the village, a basin lined with old brickwork carved of the volcanic stones that had been collected in painful labor by slaves and coolies to free the ground for cane fields. The lands next to the beach were lined with small bungalows owned by white middle-class families (on such property relations see Salverda \& Hay, 2013). Such bungalows are sometimes rented 
out to tourists or relatives visiting from Europe, Eastern Africa, and the neighboring island, Reunion. On the edges of the village there was the odd church built by one of the families who owned the local sugar estate some time in the 18th or 19th century, and next to this were larger hotels, housing 50 or so rooms and individual restaurants.

There would have been nothing unusual to the place had it not been for the surprisingly large fashion shop that looked like a factory outlet store, flew the US flag, and offered only garments with the Ralph Lauren brand name. Actually, the road connecting the UNESCO world heritage site, Le Morne Mountain, in the south with the capital was lined with such shops. However small the roadside settlement, it housed such a shop. Ralph Lauren polo shirts, trousers, and men's shirts were in abundant supply, and although I was not aware of the prices asked in Europe for such clothes, they seemed rather cheap. Only during my longer research in 2004 would I learn that back in 2003 there had been 430 Ralph Lauren shops in Mauritius - one shop for every 2,790 inhabitants - a ratio some ThirdWorld regions would be happy to see for the number of doctors per inhabitant.

Another incident that took me by surprise and would consolidate my interest in the phenomenon happened after I visited the Royal Botanical Gardens in Pamplemousses. In these gardens, the French physiocrat Pierre Poivre experimented with coffee and cane seeds stolen from British and Dutch colonial possessions in the 18th century. For these and other reasons, the gardens feature prominently in historical writings on Mauritius (Grove, 1995; Storey, 1997). I missed the bus and was happy when a taxi driver offered a ride to the next seaside resort, Grand Baie, at an incredibly low rate. Approaching Grand Baie, I learned how the price had come about. The driver suggested we should stop at a shop selling Ralph Lauren garments. I would not have to buy anything. I just had to enter, and he would earn a commission that would compensate him twofold for the reduced fare on which I had travelled. Tiredly appealing to some equivalent of a moral economy I mistakenly believed to be relevant in Mauritius, I refused to set foot in a shop selling ugly polo shirts for the petty bourgeoisie and missed out on a possibly insightful, important research experience, which I could not repeat once I returned in 2004.

This was because by then the issue of Ralph Lauren sales in Mauritius had exploded, not only on the national level, but on the level of the international garment industry. A couple of weeks before I left for my second research trip to Mauritius in February 2004, one of the most important 
knowledge platforms for the global textile and garment sector featured the following story as headline in its daily newsletters:

A Mauritius court has banned businesses on the island from manufacturing goods bearing the logo of fashion designer Polo Ralph Lauren Corp.

The United States-based company, which has objected to the practice for more than a decade, was granted a temporary injunction against Mauritian businesses making and selling unlicensed Polo apparel earlier this year.

"On Wednesday (the court) granted the company a permanent injunction," a court official said. "Local outlets are now not allowed to produce or sell goods with the Ralph Lauren name or logo."

While local retailers claim about 7,000 jobs are at risk as a result of the ruling, judge Paul Lam Shang Lee said the court had the Mauritian economy's best interests at heart.

"If thousands of people will be affected, the fault lies with those purveyors of others' ideas and works who have created the situation and who have been enjoying a very lucrative market," he said.

"The state has at heart the future of the economy of the country and most of all the desire to show the whole world that Mauritius is not anymore a safe haven for counterfeiters." (Just-Style.Com, 2004)

This charts well what was at stake in February 2004 for Mauritius. The continued sale of Ralph Lauren counterfeit garments had triggered an international dispute. Now that this dispute had been won by the American brand, the future of several hundred shops, that of thousands of Mauritian workers producing the garments, and even the reputation of the island as a national economy supporting the proper conduct of business were in jeopardy. This was particularly contentious because EPZ investors were packing up and relocating to the People's Republic of China and India in search of cheaper labor in recent years. After the establishment of the World Trade Organization (WTO), Mauritius had lost preferential quotas and with them many jobs (Neveling, 2006). The following traces the emergence of this surprisingly large and for many years legal business of counterfeit garment production and sales on Mauritius and relates this to the processes of embedding, disembedding, and reembedding markets in global capitalism.

\section{Embedding, Disembedding, and Reembedding Informal State Capitalism}

As illustrated in the preceding section, the EPZ regime established by the Mauritian state ticked the boxes that anthropologists often reserve for the 
informal economy. To generalize (and possibly exaggerate) the various viewpoints that $I$ have outlined above: Members of parliament associated the EPZ with smuggling, a large local bank suggested that EPZ investors were ripping off the state, and at least one investor felt ripped off by the very same local bank to an extent that led him to crash his car before departing for good. As I have shown, such sentiments featured prominently in debates during the 1960s, 1970s, and early 1980s, before the advent of large-scale investment in the MEPZ turned the island's economy around miraculously. And even nowadays, such stories are told again and again, making for telling legends of the early days of the MEPZ. The fact that they continue to be told is one of many indications that shady practices did not cease to exist when the boom came. I heard again and again of incidents of companies closing and taking with them all machinery overnight, so that workers arriving for the morning shift found nothing but an empty state-owned building. Also, at one point in 1990, the official stamp used to identify exports of those particular garments entering the European Union under the favorable quota regime was lost, and newspapers reported for several days on the search for it (L'Express, 1990).

Despite all this, or rather because of the state-backed anti-market that was the MEPZ, numerous Western fashion companies set up production sites in the MEPZ. Others subcontracted with an increasing number of local businesses offering such services to produce garments based on their specifications for designs and materials. One of these was Ralph Lauren. The stories I heard from local experts in the garment sector said that Ralph Lauren had had a factory in Mauritius; researchers have reported that the company used the subcontracting model (Edensor \& Kothari, 2006, p. 330). Irrespective of the business model used, Ralph Lauren moved on from Mauritius in 1990, only to wake up to a bad surprise: production in Mauritius continued. How could this happen?

Technology transfer is one of the main aims that governments pursue when setting up an EPZ. Over the years, Mauritians learned how to distinguish cheap and expensive brands, how to cut and design garments, and how to run factories, and they also learned about the profit margins for popular brand names. In addition, the sale of garments that might qualify as counterfeit is not necessarily illegal. During an internship on the shop floors of one Mauritian factory in 2004, I learned that for each order a significant surplus is produced. This depends on the overall quality levels that international brands require, which means that the quality testing in the factory and from the buyer will result in products being rejected. It is not uncommon that for an order of 10,000 men's shirts, 11,500 shirts are 
actually produced. For reasons that have to do with the production process, which is of lesser relevance here, collars and sleeves might not match, pockets might have the wrong seams, garments might become soiled, and so forth. In the factory, these "rejects" were grouped into three categories. The presentable or easily repairable ones went to the factory's tourist outlet next to a local museum that tells the long story of garment design (but nothing much about MEPZ in 2004). They were rebranded with the Mauritian company's name and sold at considerable margins. Secondcategory rejects were sold in the shop next door to people from the neighborhood, to workers, or to petty traders who would rebrand them, do additional repairs, and sell them in local markets that were frequently visited by tourists and locals. Third-category rejects would be sold by the kilogram to local tailors, who would use them for various purposes, often for creating modern-style designs and passing them on to the same merchants who bought category-two rejects. It was not possible to date the emergence of this practice, but it had evidently gone on for several years. It should be safe to assume that in this way Mauritians learned about the benefits of selling world-market factory products to tourists and thereby shortcutting global commodity chains.

In 1992 Aurdally Brothers Ltd. registered Ralph Lauren Polo as a trademark in Mauritius. The brand had never been registered in Mauritius, the Customs Controller in charge of the procedures had never heard of it, and so production and sale of Ralph Lauren garments began with legal approval. In 1994 and 1996, Ralph Lauren lawyers argued in court that the seven-year registration given to Aurdally Brothers in accordance with the Mauritian Companies Act of 1868 was illegal. They referred to the Paris Convention of 1976, which prohibited the registration of an internationally known trademark. Mauritian courts turned down appeals with reference to the Customs Controller's ignorance-based decision. Until 1997, Aurdally Brothers produced shirts, t-shirts, and trousers with similar tissues, cuts, and colors as Ralph Lauren's Polo collection and branded them accordingly (Ait-Hatrit, 2004).

Judging from my observations and discussions in Mauritius, the issue can be broken down as follows. Although Ralph Lauren garments are quite expensive, the collection consists largely of what might be called "no-fashion" garments, meaning garments with simple styles, average quality fabrics, and standard colors. A small polo-player logo, easily embroidered onto the garments, gives an aristocratic odeur. High sales prices are backed by expensive global advertisement campaigns. Target customers are suburban middle- and upper middle-class people around the world with an average 
taste of style and a strong urge to look right-wing mainstream. Many of the tourists attracted by the destination Mauritius have exactly this background. This makes for an excellent customer base with brand awareness. Arrivals of tourists have risen constantly since 1970, and in 2003 the island was counting 700,000, aiming to break the barrier of one million visitors per year (Central Statistics Office, 2004).

So it was no wonder that Aurdally Brothers' revenues from the company-owned Marson stores were impressive. In 1997 the rights to the trademark Ralph Lauren for Mauritius were sold for further commercialization to Captain Tasman for a considerable sum. The latter franchised the brand to 50 shops at a price of 50,000 Mauritian Rupees (MUR) per shop per month (Le Mauricien, 2004). This was a considerable amount for Mauritian standards, and it is evidence that there was a lot of money in the Ralph Lauren business. In 2000, the trademark registration had to be renewed. Mauritian government authorities rejected this, and a local court turned down a joint appeal of Aurdally Brothers and Captain Tasman. The country had become a member of the WTO in 1995 and was now subject to new international property rights agreements. Ralph Lauren's head office in New York also turned down an offer by Ajay Beegoo, owner of Captain Tasman, to franchise the trademark. Beegoo appealed, and the case got stuck in the Mauritian Supreme Court, meaning that now no one held trademark rights for Ralph Lauren in Mauritius (Pillay, 2004).

For some time, Ralph Lauren's US owners thought that unfortunate chapter was closed, only to wake up to a situation that was worse than in the early 1990s. Shops selling and small factories producing clothes under the label Ralph Lauren Polo had mushroomed all over the country. As I said above, there were more than 400 boutiques selling the Polo brand in Mauritius during my first field research in 2003. Small fishing villages along the coast, with no other shopping facilities than a food store and a snack bar maybe, housed at least one Ralph Lauren outlet. Arsenal, once an insignificant settlement on the main road between the tourist resorts in the north and Port Louis, had become the center of the business, with four huge outlet stores, vast car parks, special sales promotion events, and an elaborated system for attracting customers. Taxi owners, bus drivers, and guides of Mauritian tour operators - anyone who could get a tourist through the door - received anything from 100 to 500 MUR each. This was independent of sales revenues. As I learned further in my talks with taxi drivers and tour guides, they were given an additional 20 percent commission on all purchases. A tourist guide living in the same 
housing estate as I assured me that every single tour she had done between 2000 and 2004 had stopped in Arsenal before taking the tourists back to their hotels. Fees and commissions had made up more than 50 percent of her income.

From 2002 onward, Ralph Lauren increased pressure on the Supreme Court. The tide turned when the company won the support of the US government. Mauritius enjoyed favorable export quota to the United States under the African Growth and Opportunities Act since 1999, and threats to take these quota away were persuasive. The Supreme Court ruled in favor of Ralph Lauren on the 30th of January, 2004. The next day, the Association of Mauritian Textile Producers and Retailers (this is one of many such associations - despite the presumably all-encompassing name) representing the local producers and vendors of Ralph Lauren garments claimed that 10,000 jobs would be lost if operations were closed. The day after the court decision, thousands of employees of now-illegal factories and shops demonstrated (Le Mauricien, 2004). Reuters quoted the Captain Tasman owner:

\footnotetext{
This is a typical example of powerful multinational companies coming in with expensive lawyers and lots of money to disrupt the lives of people in poorer countries. How can we fight a huge American company? [...] so we are asking Ralph Lauren to give us 18 months to help us restructure and retrain our staff. But they have no humanitarian face. (Bhalla, 2004)
}

Such rhetoric was well received by the Mauritian public. Since the foundation of the WTO in 1995, the EPZ had gone through a series of crises. The textile and garment sector made up the lion's share of companies, and with the intended phasing out of quota regimes on a global scale, Mauritius was constantly threatened with the loss of one of its major advantages over countries such as the People's Republic of China, India, or Bangladesh, where labor was cheaper. Particularly since the early 2000s, tens of thousands of workers had lost their jobs because of relocations, and critique of EPZ investors had intensified. One other striking development had been that Mauritian companies had never managed to gain ground in Western markets with their own fashion labels. Even the largest Mauritian company, Floreal Knitwear, for a long time the world's second largest producer of knitted woolens, had seen its own brand, Harris Wilson, incur massive losses in Europe (Neveling, 2006). In this climate it was no wonder that many Mauritians actually regarded Ralph Lauren as the most successful Mauritian fashion label. The affair was on the verge of turning into "Ralph Lauren against Mauritius." 
The US company had for some time fueled such sentiments. Despite the favorable Supreme Court verdict in late January 2004, Ralph Lauren had initially taken every measure to make sure Mauritians would stop selling counterfeit garments, for good and instantly so. Therefore, Ralph Lauren had sent its own law enforcer to the island. This move was interpreted as a sign of distrust of the Mauritian police, which had set up a special unit solely to support the US company. Still, Ralph Lauren's envoy, Marcel Lapierre, went from shop to shop, threatened owners with high fines and offered individual phase-out agreements - a three-month right to sell the rest of their stock in exchange for 5,000 MUR. Mauritian newspapers portrayed Lapierre as a colonial-style cowboy, and the fact that he wore a cowboy hat while carrying out his duties played into their hands.

The heat was taken out of the issue when this policy was revoked. Ralph Lauren sold licenses for the sale of existing stocks until the end of 2004 to any existing shop willing to pay one million MUR. For the large shops in Arsenal and elsewhere, this was a bargain, considering that across the island there had been a monthly turnover of 200 million MUR. As the news spread, tourists rushed to the shops as if they were the new Klondike, happy to buy t-shirts for 800 MUR that would cost the equivalent of 3,000 MUR in Western countries (Bhuckory, 2004).

After the Mauritian companies producing and selling Ralph Lauren had obtained some air to breathe by paying one million MUR compensation each in order to restructure and regroup, Captain Tasman set up a fashion brand called "Liberty" - again advertising the garments with the US flag on shop fronts, but to my knowledge without ever coming even close to the sales figures of Ralph Lauren Mauritian style. At the time of my most recent research in Mauritius in November 2012, all Liberty shops had gone out of business. There were, however, a few brandnamed Ralph Lauren shops, located in the main tourist spots, at the Caudan Waterfront in Port Louis, in the upmarket shopping district of Grande Baie, and in the duty-free areas of the international airport's arrival and departure terminals. These were run by locals who franchised from Ralph Lauren and imported garments from overseas. As I was told, prices were the same as those in Europe or Asia, and the purpose of the shops was not necessarily to make high turnovers but to make sure that "real" Ralph Lauren garments were visible on the Mauritian market, so that no one would ever again get the idea that the label was there for the taking. 


\section{CONCLUSIONS: THE THREE SHADES OF EMBEDDEDNESS AND THE MAINTENANCE OF INFORMAL STATE CAPITALISM IN THE GLOBAL EPZ REGIME}

The above shows that smooth running of capitalist anti-markets is not dependent only on state capitalism and its capacity to forge successful alliances with international capital, as happened in the 1970s and particularly so in the boom years of the MEPZ between 1985 and 1995. The initial phase of MEPZ operations was shaped by mutual allegations of informal dealings from all actors involved: the state, capital, and labor. The boom years to some degree eased over such allegations. In many ways, the MEPZ was embedded as an anti-market within Mauritian society in those years. Workers who had stayed with a single company for many years achieved a considerable degree of prosperity, and class struggle took a position at the backstage of Mauritian politics. In those years an expression emerged that equated the MEPZ with the mother's household. "La cas maman" is a central institution in Mauritian society, where one can see men in their mid50s going over to their mother's house each Sunday and where Mother's Day is one of the most important shopping events of the year. But already within that period of embeddedness, the seeds were sown for a disembedding of the anti-market that kicked in as soon as MEPZ operations declined. The wider framework for this was, of course, the foundation of the WTO, which brought significant changes in the global trading system that were disadvantageous for Mauritius.

But there is more to capitalist anti-markets than the analysis of the WTO regulations and their local repercussions in national economies, factories, and households will tell us. The example of counterfeit Ralph Lauren garments and their large-scale production in Mauritius powerfully illustrates that local producers can successfully achieve at least some of the trickledown effects that national governments hope to gain from EPZ operations. Technology transfer in Mauritius was mainly possible, however, because national trademark legislation had not yet been adjusted to the island's embeddedness into the global commodity chain for textiles and garments. In a sense, international agreements preventing the production of counterfeit clothes signed in the mid-1990s were "late-comers" from the viewpoint of the Multi-Fiber Arrangement of 1974, which had made it possible for Mauritius to gain access to the global garment chain in the first place. ${ }^{5}$ 
Western fashion chains such as Ralph Lauren never saw Mauritius as a market for selling their products. In the early 1990s, after two decades of garment production, Mauritian businesspeople had sufficient knowledge to replicate Ralph Lauren designs. More importantly though, they realized that they were ideally positioned to cut out important nodes of the global garment commodity chain. They could sell their products directly to customers from Western markets - to those who came to Mauritius as tourists. Thus, Aurdally Brothers and Captain Tasman had made ends meet; the ends of two commodity chains - of the tourism industry and of the garment industry. The WTO, which initially distorted the embeddedness of the MEPZ as its policies since 1995 caused rising unemployment and discontent, would in the 2000s serve as an important, albeit unintended, mediator for a reembedding of the MEPZ, at least in terms of the Ralph Lauren case. Intellectual property rights agreements signed by Mauritius as a WTO member closed the gap that I have identified above. The decline of the MEPZ increased dependency on the quota that were left from such preferential agreements as the US African Growth and Opportunities Act, and this caused sufficient fear for the Mauritian Supreme Court to reverse its earlier decisions and stop dragging out the Ralph Lauren case.

From this angle, embeddedness - not as a Polanyian end to a precapitalist multi-faceted social order, but as a process-oriented analysis of the impact that the patterns of regulating capitalist exploitation have on a given place such as Mauritius - is useful to identify the contests that emerge as new actors enter the capitalist anti-market and old actors exit. Obviously, embeddedness, then, also retains its ability to identify the degree of discontent that exploitation nurtures in societies as they move from economic decline to growth, to decline and so on.

My analysis of Mauritian EPZ operations over four decades reveals that a juxtaposition of informal economic activities and state capitalism provides little gain but is rather misleading. This has to do with the fact that the patterns employed for regulating capitalism are neither rational nor do they have much to do with "the market." One might object that the highly exploitative regime of EPZs provides a case that plays into the cards of such a dismissal. But then the success of an EPZ did not and does not rest on exploitation alone. Other factors, such as preferential quotas for the markets of wealthy nations, play a much more important role, not least in the present, when there are around 3,500 EPZs with more than 60 million workers in approximately 130 countries (Neveling, 2015a).

While the informal-formal distinction, then, is rather misleading and best used to capture the native's point of view, maintaining the concept of 
embeddedness by transferring it to the analysis of capitalist anti-markets is beneficial. The relations among state, capital, and labor are constantly shifting in global manufacturing, as much in the past as in the present era, which is often mistakenly identified as radically different from earlier periods because it is "neoliberal" (Baca, 2005, 2010; Neveling, 2006; Neveling, forthcoming). In any given place there will be periods when such relations are rather stable (again, not because they show a high degree of rationalization and can therefore be labeled "formal"). Instead, the "logic of the market" that the case of the MEPZ and the counterfeit production of Ralph Lauren garments reveals matches the observation that "[M]arkets are by necessity legal-politically and socio-culturally embedded [... or disembedded by] a framework within which only that which is calculable and economically efficient is valid." What others have poignantly identified as the way the "logic of the market [...] can emerge" (Rottenburg et al., 2000, p. 24, my addition/omission) may be called a "logic of the anti-market." This inhibits a rationality that is shared by and reserved for a given number of actors at a given moment in space and time. But there are always others who contest that very logic, hoping either to be invited to the ranks of those who benefit from the regulations of the capitalist anti-market or hoping to change the patterns of regulation once and for all so that a different logic may emerge that does not put exploitation and accumulation at the center of economic activity.

\section{NOTES}

1. In sum, Hart takes a fundamentally Weberian view on the economy, arguing, for example, that "society everywhere is held together by force" in his later work (Hart, 2005, p. 4).

2. Until today, such networks produce much more meaningful "cross-cutting ties" than those identified by anthropologists (e.g., Eriksen, 1998, pp. 103-36), who look at Mauritius through the "ethnic lens," to borrow a term that Glick-Schiller and others have coined as a critique of migration studies (Glick-Schiller, Çaglar, \& Guldbrandsen, 2006).

3. This history is rather common knowledge in Mauritius as well as in the international development community concerned with the island. The literature on these developments is abundant, and it would be hard to find any Mauritian who does not know about the diversification from sugar to textiles/garments and tourism (for an overview of several histories of Mauritian consortia and their venture from sugar into textiles/garments see: Grégoire \& Lemoine, 2011). My own work covers the historical development since around 1800 of what is today the CIEL Holding, which has three main branches and hundreds of sister companies in agriculture, textiles/ 
garments, IT and tourism, and real estate (cf. Neveling, 2012). Salverda (2010, pp. 110-154) also devotes a full chapter to "Land, Textiles and Tourists," although this has names anonymized. There is also a standard work of reference on the Mauritian sugar industry since its beginning, and the interested reader will find that there are many more hotels that bear the names of former estates (Rouillard, 1964-1979).

4. This is both a reflection of tourist arrival numbers during the time of my research (see Central Statistics Office, 2004) and of my observations and interactions during field research. It is noteworthy that the global backpackers' bible, Lonely Planet lists hardly any low budget accommodations for Mauritius (cf. Bindloss, Singh, Swaney, \& Strauss, 2001).

5. This is one of many examples why the quest for a critical political economy in anthropology is not to fight the windmills of rational choice theory and neo-/classical economics. Rational choice in the sense that neoclassical economists would want to have it does not exist and has never existed. Therefore, it is futile to trace when the relationship between economy and society went sour. Any such effort would imply that this relationship has not been sour all along and would this way neglect the fact that inequality is a persistent feature of human history. Institutions, such as markets and anti-markets, are "derivative and adaptive and not the cause or - contra Polanyi - the social embedment of the economic process" (Frank, 1998, p. 206). Change and continuity in the global system and within global capitalism are dependent on more complex processes than an institutional view can provide. What the institutional view can provide though, is a middle-range analysis of the way institutions are adapted to the wider patterns regulating capitalist exploitation. Anything beyond that will be discussed in future publications.

\section{ACKNOWLEDGMENTS}

This paper develops further findings that I presented at the EASA conference in 2006 (paper title: "Formal or Informal Miracle: Mauritian Economic Globalisation in the 20th Century") and at the 2010 History of Commodity Chains Research Group Meeting, University of Konstanz (paper title: "Ralph Lauren Mauritian Style: Methodological and Epistemological Challenges in the Study of Competing Notions of 'Liberty,' Legality, and Dependency within Global Commodity Chains"). I would like to thank the participants and conveners for their valuable comments. I have also benefitted from two anonymous reviewers' comments on an earlier version of this paper. Natalia Buier, Robert Heinze, and Joe Trapido have given important stimulus to take my thoughts further, and Donald Wood has been an excellent editor. Research has been funded by the MartinLuther-University, Halle-Wittenberg, and by the Swiss National Science Foundation (grant no. 140484). The usual disclaimers apply. 


\section{REFERENCES}

Ait-Hatrit, S. (2004, February 17). Ralph Lauren contre Maurice: La marque américaine déclare la guerre à la contrefacon. http://www.afrik.com [Online]. Retrieved from http://www. afrik.com/article7059.html. Accessed on September 23, 2013.

Aladin, I. (1993). Economic miracle in the Indian Ocean: Can Mauritius show the way? Stanley, Republic of Mauritius: Editions de l'Océan Indien.

Baca, G. (2005). Legends of fordism: Between myth, history, and foregone conclusions. In B. Kapferer (Ed.), The retreat of the social: The rise and rise of Reductionism (pp. 31-46). New York, NY: Berghahn Books.

Baca, G. (2010). Conjuring crisis : Racism and civil rights in a southern military city. New Brunswick, NJ: Rutgers University Press.

Barber, B. (1995). All economies are "embedded": The career of a concept, and beyond. Social Research, 62(2), 387-413.

Bhalla, N. (2004). Ralph Lauren closures hurt Mauritius-retailers. Reuters, February 12 [Online]. Retrieved from http://www.reuters.com. Accessed on February $13,2004$.

Bhuckory, K. (2004). Achats de fin d'année: Ralph Lauren tire sa révérence en braderie. L'Express, February 25.

Bindloss, J., Singh, S., Swaney, D., \& Strauss, R. (2001). Lonely Planet. Mauritius, Réunion \& Seychelles. Melbourne: Lonely Planet Publications.

Blim, M. (2000). Capitalisms in late modernity. Annual Review of Anthropology, 29, 25-38.

Blyth, M. (2003). Great transformations: Economic ideas and institutional change in the twentieth century. Cambridge: Cambridge University Press.

Boyenge, J.-P. S. (2007). ILO database on export processing zones (Revised). ILO Working Papers [Online], p. 251. Retrieved from http://www.ilo.org/public/english/dialogue/ sector/themes/epz/epz-db.pdf. November 27, 2009.

Braudel, F. (1992). Civilization and capitalism, 15th-18th century: The wheels of commerce. Berkeley, CA: University of California Press.

Burn, N. (1996). Mauritius. In U. Kothari \& V. Nababsing (Eds.), Gender \& industrialisation: Mauritius, Bangladesh, Sri Lanka (pp. 33-79). Stanley, Rose Hill: Editions de l'Océan Indien.

Carrier, J. G. (2012). Anthropology after the crisis. Focaal, 64, 115-128.

Central Statistics Office. (2004). Mauritius in figures 2003. Port Louis: Central Statistics Office.

Colonial Office. (1959, July 13). Colonial office to meade. London School of Economics Archive, MEADE 5/9.

Cross, J. (2010). Neoliberalism as unexceptional: Economic zones and the everyday precariousness of working life in South India. Critique of Anthropology, 30(4), 355-373.

Debates of the Legislative Assembly. (1968). Second session, 3rd legislative assembly December, 12, 1968, debates No. 38. Port Louis, Mauritius: Authority of the Assembly/Mauritius Government Printer.

Debates of the Legislative Assembly. (1970). Third session, 3rd legislative assembly March 10-June 30, 1970 debates Nos. 1-19. Port Louis, Mauritius: Authority of the Assembly/Mauritius Government Printer.

Development Bank of Mauritius/Gustave Rey. (undated, around 1971). Industrial estate coromandel, preliminary report. Washington, DC: World Bank Archives, MAS-CR411R/C (alt. number: DOC.H/03.012(B)). 
Edensor, T., \& Kothari, U. (2006). Extending networks and mediating brands: Stallholder strategies in a Mauritian market. Transactions of the Institute of British Geographers, $31(3), 323-336$.

Eriksen, T. H. (1998). Common denominators: Ethnicity, nation-building and compromise in Mauritius. Oxford: Berg.

Evers, H.-D. (1987). Schattenwirtschaft, Subsistenzproduktion und informeller Sektor. Wirtschaftliches Handeln jenseits von Markt und Staat. Kölner Zeitschrift für Soziologie und Sozialpsychologie (Sonderheft: Soziologie Wirtschaftlichen Handelns), Sonderheft, 28, 353-366.

Fernández-Kelly, M. P. (1983). For we are sold, I and my people: Women and industry in Mexico's frontier. Albany, NY: State University of New York Press.

Forget, P. A. (1983). Wishing a future for the EPZ is not enough. Port Louis: Mauritius Commercial Bank.

Frank, A. G. (1998). ReOrient: Global economy in the Asian Age. Berkeley, CA: University of California Press.

Glick Schiller, N., Çaglar, A., \& Guldbrandsen, T. C. (2006). Beyond the ethnic lens: Locality, globality, and born-again incorporation. American Ethnologist, 33(4), $612-633$.

Greenaway, D., \& Milner, C. (1991). Did Mauritius really provide a "case study in malthusian economics"? Journal of International Development, 3, 325-338.

Grégoire, E., \& Lemoine, G. (2011). Les entrepreneurs Mauriciens. In E. Grégoire, V. Y. Hookoomsingh, \& G. Lemoine (Eds.), Maurice: De l'île sucrière à l'île des savoirs (pp. 183-223). Mauritius: Éditions Le Printemps Ltée.

Grove, R. (1995). Green imperialism: Colonial expansion, tropical island Edens and the origins of environmentalism, 1600-1860. Cambridge: Cambridge University Press.

Hart, K. (1973). Informal income opportunities and urban employment in Ghana. The Journal of Modern African Studies, 11(1), 61-89.

Hart, K. (2005). Formal bureaucracy and the emergent forms of the informal economy. Research Paper, UNU-WIDER, United Nations University (UNU): No. 2005/11, ISBN 9291906905.

Just-Style.Com. (2004, February 4). Mauritius: Ralph Lauren stores closed after injunction. Retrieved from http://www.just-style.com/news/ralph-lauren-stores-closed-after-injunction_id68500.aspx. Accessed on February 4, 2004.

Kalb, D. (2012). Thinking about neoliberalism as if the crisis was actually happening. Social Anthropology, 20(3), 318-330.

Le Mauricien. (2004). Litige autour de la marque Ralph Lauren: Chronique d'une polémique annoncée. Le Mauricien, February 17.

L'Express. (1971). Stratégie du Développement 1971-1980: Discipline, travail et participation. L'Express, January 26, p. 1.

L'Express. (1990). Le tampon EUR1 disparaît du ministère du Commerce. L'Express, February 14.

Ministry of Commerce \& Industry. (1973). Mauritius exports. Port Louis: Ministry of Commerce \& Industry.

Ministry of Commerce \& Industry (Mauritius). (1973). Advertisement: The national development plan of Mauritius. The Times, March 5.

Ministry of Commerce \& Industry (Mauritius). (1976). Advertisement: Mauritius export processing zones (MEPZ). The Times, June 30. 
Nash, J. C., \& Fernández-Kelly, M. P. (1983). Women, men, and the international division of labor. Albany, NY: State University of New York Press.

Neveling, P. (2006). Spirits of capitalism and the De-alienation of workers: A historical perspective on the Mauritian garment industry. SCM Working Paper Series [Online], p. 2. Retrieved from http://www.scm.uni-halle.de/gsscm/die_graduiertenschule/online_ papers/2006/mauritian garment industry/. Accessed on January 14, 2010.

Neveling, P. (2012). Manifestationen der Globalisierung. Kapital, Staat und Arbeit in Mauritius, 1825-2005 [Manifestations of globalisation. Capital, state, and labour in Mauritius, 1825-2005]. DPhil thesis, Martin-Luther-University Library, Halle/Saale.

Neveling, P. (2014). Structural contingencies and untimely coincidences in the making of neoliberal India - The Kandla Foreign Trade Zone, 1965-1991. Contributions to Indian Sociology, 48(1), 17-43.

Neveling, P. (2015a). Export processing zones and global class formation. In J. Carrier \& D. Kalb. (Eds.), Anthropologies of class: Power, practice, and inequality. Cambridge: Cambridge University Press.

Neveling, P. (2015b). Flexible capitalism and transactional orders in colonial and postcolonial Mauritius: A post-occidentalist view. In J. Kjaerulf (Ed.), Flexible capitalism: Exchange and ambiguity at work (pp. 286-324). Oxford: Berghahn.

Neveling, P. (forthcoming). The global spread of export processing zones and the 1970s as a decade of consolidation. In K. Andersen, S. Müller, \& R. Richter (Eds.), Changes in social regulation - State, economy, and social protagonists since the 1970s. Oxford: Berghahn Books.

Ong, A. (1987). Spirits of resistance and capitalist discipline: Factory women in Malaysia. Albany, NY: State University of New York Press.

Ong, A. (2006). Neoliberalism as exception: Mutations in citizenship and sovereignty. Durham, NC: Duke University Press.

Pillay, B. (2004). L'affaire Ralph Lauren: le vrai du vaux! Chamber News, February 20 [Online]. Retrieved from http://www.mcci.org. Accessed on February 20, 2004.

Polanyi, K. (1957). The economy as instituted process. In K. Polanyi, C. M. Arensberg, \& H. W. Pearson (Eds.), Trade and markets in the early empires (pp. 243-270). Chicago, IL: Henry Regnery Company.

Polanyi, K. (1977). The great transformation: Politische und ökonomische Ursprünge von Gesellschaften und Wirtschaftssystemen. Frankfurt/Main: Suhrkamp.

Portes, A., \& Benton, L. (1984). Industrial development and labor absorption: A reinterpretation. Population and Development Review, 10(4), 589-611.

Rottenburg, R., Kalthoff, H., \& Wagener, H.-J. (2000). Introduction. In search for a new bed: Economic representations and practices. In R. Rottenburg, H. Kalthoff, \& H.-J. Wagener (Eds.), Facts and figures: Economic representations and practices (pp. 9-34). Marburg: Metropolis Verlag.

Rouillard, G. (1964-1979). Histoire des domaines sucriers de l'ile Maurice. Les Pailles/Ile Maurice: The General Printing \& Stationary Company Ltd.

Safa, H. I. (1995). The myth of the male breadwinner: Women and industrialization in the Caribbean. Boulder, CO: Westview Press.

Salverda, T. (2010). Sugar, sea and power. PhD thesis, Vrije Universiteit.

Salverda, T., \& Hay, I. (2013). Balancing (re) distribution: Franco-Mauritians landownership in the maintenance of an elite position. Journal of Contemporary African Studies, 31(3), $503-521$. 
Schnepel, B. (2009). Two beaches: The globalization of Mauritian waterfronts. In V. Y. Hookoomsing, R. Ludwig, \& B. Schnepel (Eds.), Multiple identities in action: Mauritius and some antillean parallelism (pp. 287-317). Berlin: Peter Lang.

Schnepel, B. \& Schnepel, C. (2008). "Finger weg von unserem Strand": Tourismus auf einer multikulturellen "Paradiesinsel" (Mauritius) im Indischen Ozean. Wien.

Schnepel, B., \& Schnepel, C. (2009). The Mauritian Séga: Performing identity in a multi-ethnic setting. In V. Y. Hookoomsing, R. Ludwig, \& B. Schnepel (Eds.), Multiple identities in action: Mauritius and the antillean parallelism (pp. 275-286). Frankfurt a.M.: Peter Lang.

Storey, W. K. (1997). Science and power in colonial Mauritius. Rochester, NY: University of Rochester Press. 